\title{
Front Matter: Volume 8634
}

, "Front Matter: Volume 8634," Proc. SPIE 8634, Quantum Dots and

Nanostructures: Synthesis, Characterization, and Modeling X, 863401 (12 April 2013); doi: 10.1117/12.2022939

SPIE. Event: SPIE OPTO, 2013, San Francisco, California, United States 


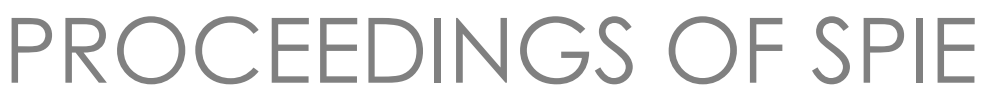

\section{Quantum Dots and Nanostructures: Synthesis, Characterization, and Modeling $X$}

Kurt G. Eyink

Diana L. Huffaker

Frank Szmulowicz

Editors

4-6 February 2013

San Francisco, California, United States

Sponsored and Published by

SPIE

Volume 8634 
The papers included in this volume were part of the technical conference cited on the cover and title page. Papers were selected and subject to review by the editors and conference program committee. Some conference presentations may not be available for publication. The papers published in these proceedings reflect the work and thoughts of the authors and are published herein as submitted. The publisher is not responsible for the validity of the information or for any outcomes resulting from reliance thereon.

Please use the following format to cite material from this book:

Author(s), "Title of Paper," in Quantum Dots and Nanostructures: Synthesis, Characterization, and Modeling $X$, edited by Kurt G. Eyink, Diana L. Huffaker, Frank Szmulowicz, Proceedings of SPIE Vol. 8634 (SPIE, Bellingham, WA, 2013) Article CID Number.

ISSN: 0277-786X

ISBN: 9780819494030

Published by

SPIE

P.O. Box 10, Bellingham, Washington 98227-0010 USA

Telephone +1 3606763290 (Pacific Time) · Fax +1 3606471445

SPIE.org

Copyright @ 2013, Society of Photo-Optical Instrumentation Engineers.

Copying of material in this book for internal or personal use, or for the internal or personal use of specific clients, beyond the fair use provisions granted by the U.S. Copyright Law is authorized by SPIE subject to payment of copying fees. The Transactional Reporting Service base fee for this volume is $\$ 18.00$ per article (or portion thereof), which should be paid directly to the Copyright Clearance Center (CCC), 222 Rosewood Drive, Danvers, MA 01923. Payment may also be made electronically through CCC Online at copyright.com. Other copying for republication, resale, advertising or promotion, or any form of systematic or multiple reproduction of any material in this book is prohibited except with permission in writing from the publisher. The CCC fee code is 0277-786X/13/\$18.00.

Printed in the United States of America.

Publication of record for individual papers is online in the SPIE Digital Library.

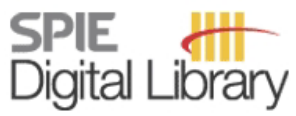

SPIEDigitalLibrary.org

Paper Numbering: Proceedings of SPIE follow an e-First publication model, with papers published first online and then in print and on CD-ROM. Papers are published as they are submitted and meet publication criteria. A unique, consistent, permanent citation identifier (CID) number is assigned to each article at the time of the first publication. Utilization of CIDs allows articles to be fully citable as soon as they are published online, and connects the same identifier to all online, print, and electronic versions of the publication. SPIE uses a six-digit CID article numbering system in which:

- The first four digits correspond to the SPIE volume number.

- The last two digits indicate publication order within the volume using a Base 36 numbering

system employing both numerals and letters. These two-number sets start with 00, 01, 02, 03, 04, 05, 06, 07, 08, 09, 0A, 0B ... 0Z, followed by 10-1Z, 20-2Z, etc.

The CID Number appears on each page of the manuscript. The complete citation is used on the first page, and an abbreviated version on subsequent pages. Numbers in the index correspond to the last two digits of the six-digit CID Number. 


\section{Contents}

$\checkmark$ Conference Committee

vii Group IV photonics for the mid infrared (Plenary Paper) [8629-1]

R. Soref, The Univ. of Massachusetts at Boston (United States)

xxiii Light in a twist: optical angular momentum (Plenary Paper) [8637-2]

M. J. Padgett, Univ. of Glasgow (United Kingdom)

\section{DEVICES I}

863407 Systematic investigation of the temperature behavior of InAs/InP quantum nanostructure passively mode-locked lasers [8634-5]

K. Klaime, R. Piron, INSA, CNRS, Univ. Européenne de Bretagne (France); F. Grillot, INSA, CNRS, Univ. Européenne de Bretagne (France) and Lab. Traitement et Communication de I'Information, CNRS, Télécom ParisTech (France); M. Dontabactouny, S. Loualiche, A. Le Corre, INSA, CNRS, Univ. Européenne de Bretagne (France); K. Yvind, Technical Univ. of Denmark (Denmark)

\section{DEVICES II}

$8634 \mathrm{OA}$ Influence of low energy $\mathrm{H}$ - ion implantation on the electrical and material properties of quaternary alloy $\left(\operatorname{In}_{0.21} \mathrm{Al}_{0.21} \mathrm{Ga}_{0.58} \mathrm{As}\right)$ capped InAs/GaAs n-i-n QDIPs [8634-6]

A. Mandal, H. Ghadi, Indian Institute of Technology Bombay (India); K. L. Mathur, Sardar Vallabhbhai National Institute of Technology (India); A. Basu, N. B. V. Subrahmanyam, P. Singh, Bhabha Atomic Research Ctr. (India); S. Chakrabarti, Indian Institute of Technology Bombay (India)

\section{GROWTH AND CHARACTERIZATION I}

$8634 \mathrm{OB}$ Molecular beam epitaxial growth and characterization of InGaN/GaN dot-in-a-wire nanoscale heterostructures: toward ultrahigh efficiency phosphor-free white light emitting diodes (Invited Paper) [8634-8]

Z. Mi, H. P. T. Nguyen, S. Zhang, K. Cui, M. Djavid, McGill Univ. (Canada)

\section{PLASMONICS/COLLOIDAL I}

8634 OG Using confocal microscopy to characterize nanoplasmonic structures responsible for light transmission [8634-13]

M. T. Carvalho, Univ. de São Paulo (Brazil); M. Bezerra, Univ. Federal de Pernambuco (Brazil) and Univ. de São Paulo (Brazil); E. Marega Jr., B.-H. V. Borges, Univ. de São Paulo (Brazil);

F. D. Nunes, Univ. Federal de Pernambuco (Brazil) and Univ. de São Paulo (Brazil) 
$8634 \mathrm{OH}$ Probing light-matter interactions at the nanoscale with a deterministically positioned single quantum dot [8634-14]

C. Ropp, Z. Cummins, R. Probst, S. Qin, J. T. Fourkas, B. Shapiro, E. Waks, Univ. of Maryland, College Park (United States)

\section{PLASMONICS/COLLOIDAL II}

8634 OK Energy transfer in monodisperse quantum dot solids in the presence of self-organized array of metallic nanoparticles [8634-17]

S. M. Sadeghi, R. G. West, The Univ. of Alabama in Huntsville (United States)

$8634 \mathrm{OL}$ Control of photophysical and photochemistry of colloidal quantum dots via metal and metal-oxide coated substrates [8634-18]

S. M. Sadeghi, The Univ. of Alabama in Huntsville (United States); A. Nejat, Boston Univ. (United States)

\section{GROWTH AND CHARACTERIZATION II}

$8634 \mathrm{OP}$ Efficient Ga(As)Sb quantum dot emission in AlGaAs by GaAs intermediate layer [8634-22] T. H. Loeber, J. Richter, J. Strassner, C. Heisel, C. Kimmle, H. Fouckhardt, Technische Univ. Kaiserslautern (Germany)

8634 OR Unveiling structural properties of self-assembled quantum dots [8634-24]

M. Gunasekera, C. Rajapaksha, A. Freundlich, Univ. of Houston (United States)

\section{POSTER SESSION}

8634 OT Stability studies of lead sulfide colloidal quantum dot films on glass and GaAs substrates [8634-26]

J. S. Wang, E. H. Steenbergen, H. E. Smith, L. Grazulis, J. A. Massengale, B. Ullrich,

G. J. Brown, Air Force Research Lab. (United States)

$8634 \mathrm{OU}$ Energy transfer in mixtures of quantum dots of different sizes studied by thermal lens technique [8634-27]

V. M. Martins, A. F. G. do Monte, A. A. Andrade, D. N. Messias, Univ. Federal de Uberlândia (Brazil)

8634 OV Multi-spectral InAs/GaAs-based quantum dot infrared photodetector with quaternary (InAIGaAs) capping operates at low bias voltage [8634-28]

S. Adhikary, S. Chakrabarti, Indian Institute of Technology Bombay (India); Y. Aytac,

A. G. U. Perera, Georgia State Univ. (United States) 


\section{Conference Committee}

Symposium Chair

David L. Andrews, University of East Anglia Norwich (United Kingdom)

Symposium Cochairs

Alexei L. Glebov, OptiGrate Corporation (United States)

Klaus P. Streubel, OSRAM GmbH (Germany)

Program Track Chair

Ali Adibi, Georgia Institute of Technology (United States)

Conference Chairs

Kurt G. Eyink, Air Force Research Laboratory (United States)

Diana L. Huffaker, University of California, Los Angeles (United States)

Frank Szmulowicz, University of Dayton Research Institute

(United States)

Conference Program Committee

Massimo De Vittorio, Università del Salento (Italy)

Michael D. Gerhold, U.S. Army Research Office (United States)

Axel Hoffmann, Technische Universität Berlin (Germany)

Vinod M. Menon, Queen's College (United States)

Philip J. Poole, National Research Council Canada (Canada)

Jian Xu, The Pennsylvania State University (United States)

Session Chairs

OPTO Plenary Session

David L. Andrews, University of East Anglia Norwich (United Kingdom)

Alexei Glebov, OptiGrate Corporation (United States)

Devices I and II

Alberto Bramati, Université Pierre et Marie Curie (France)

Devices II

Alberto Bramati, Université Pierre et Marie Curie (France)

Growth and Characterization I

Zetian Mi, McGill University (Canada) 
Plasmonics/Colloidal I

Jeffrey Owrutsky, U.S. Naval Research Laboratory (United States)

Plasmonics/Colloidal II

Alexander L. Efros, U.S. Naval Research Laboratory (United States)

Growth and Characterization II

Andre Strittmatter, Technische Universität Berlin (Germany) 